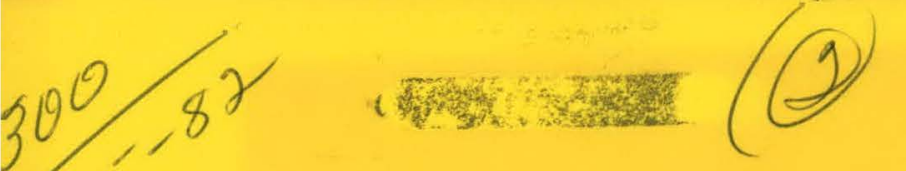

h. 6343 SOLAR/0091-81/13

(DE82007150)

\title{
GUIDELINES FOR SELECTING A SOLAR HEATING, COOLING OR HOT WATER DESIGN
} December 1981
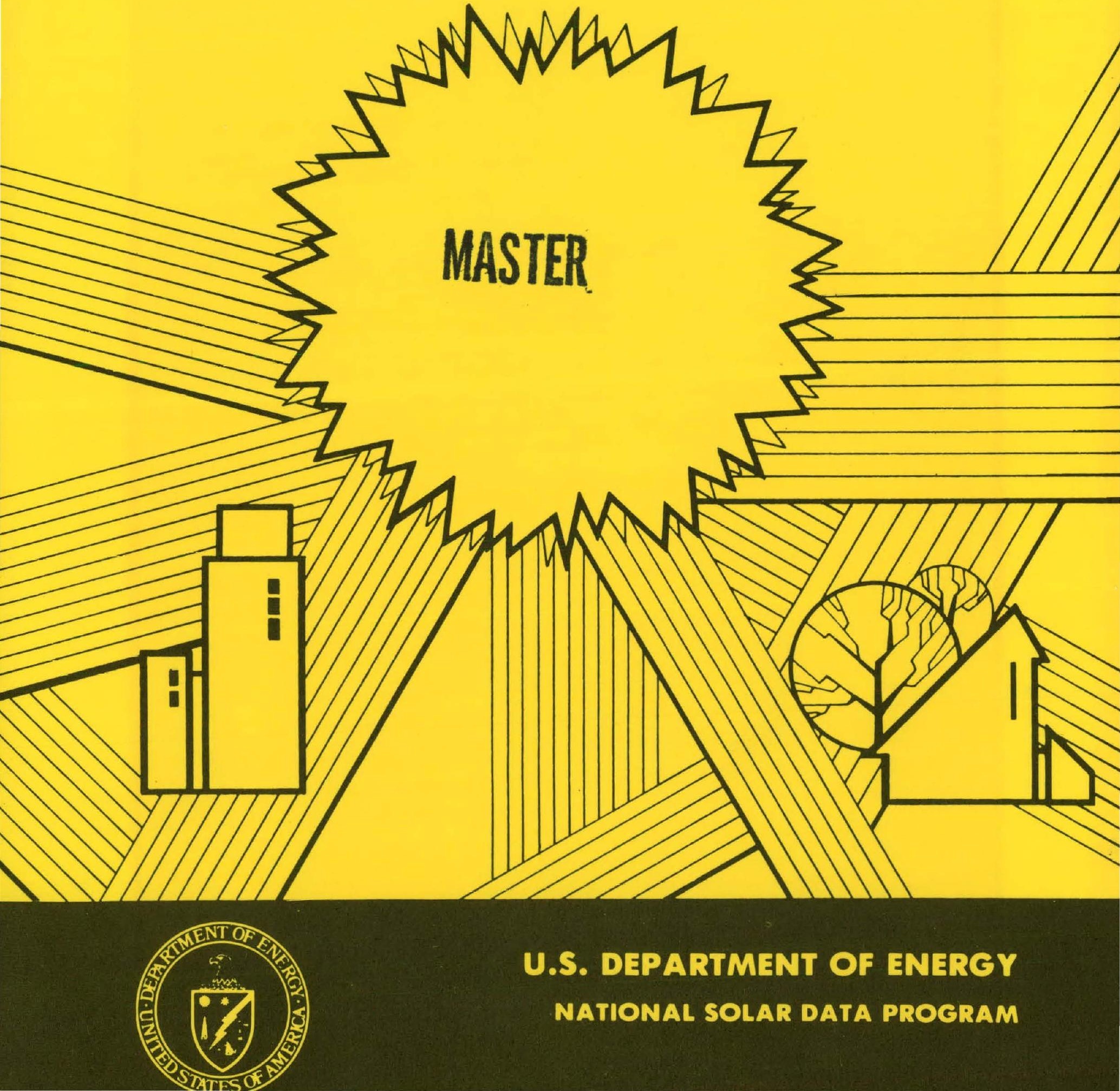

U.S. DEPARTMENT OF ENERGY NATIONAL SOLAR DATA PROGRAM 


\section{DISCLAIMER}

This report was prepared as an account of work sponsored by an agency of the United States Government. Neither the United States Government nor any agency Thereof, nor any of their employees, makes any warranty, express or implied, or assumes any legal liability or responsibility for the accuracy, completeness, or usefulness of any information, apparatus, product, or process disclosed, or represents that its use would not infringe privately owned rights. Reference herein to any specific commercial product, process, or service by trade name, trademark, manufacturer, or otherwise does not necessarily constitute or imply its endorsement, recommendation, or favoring by the United States Government or any agency thereof. The views and opinions of authors expressed herein do not necessarily state or reflect those of the United States Government or any agency thereof. 


\section{DISCLAIMER}

Portions of this document may be illegible in electronic image products. Images are produced from the best available original document. 


\title{
DISCLAIMER
}

\begin{abstract}
"This report was prepared as an account of work sponsored by an agency of the United States Government. Neither the United States Government nor any agency thereof, nor any of their employees, makes any warranty, express or implied, or assumes any legal liability or responsibility for the accurucy, cnmpleteness, or usefulness of any information, apparatus, product, or process disclosed, or represents that its use would not infinge privatoly owned rights. Reference herein to any spccific commercial product, process, or service by trade name, trademark, manufacturer, or otherwise, does not necessarily constitute or imply its endorsement, recommendation, or favoring by the United States Government or any agency thereof. The views and opinions of authors expressed herein do not necessarily state or reflect those of the United States Government or any agency thereof."
\end{abstract}

This report has been reproduced directly from the best available copy.

Available from the National Technical Information Service, U. S. Department of Commerce, Springfield, Virginia 22161.

\section{Prire. Printed Copy A02 \\ Microfiche AUI}

Codes are used for pricing all publications. The code is determined by the number of pages in the publication. Information pertaining to the pricing codes can be found in the current issues of the following publications, which are generally available in most libraries: Energy Research Abstracts, (ERA); Government Reports Aniwuncements and Index (GRA and I); Scientific and Technical Abstract Reports (STAR); and publication, NTIS-PR-360 available from (NTIS) at the above address. 
SOLAR/0091-81/13

(DE82007150)

Distribution Category UC-59

GUIDEL INES FOR SELECTING A SOLAR HEATING, COOLING OR HOT WATER DESIGN

December 1981

Prepared by:

Charles J. Kelly, Jr.

Approved:

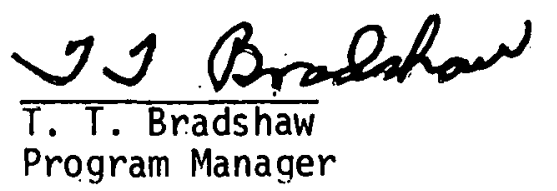

Vitro Laboratories Division Automation Industries, Inc. 14000 Georgia Avenue

Silver Spring, Maryland 20910

The National Solar Data Network

Departilient of Energy Contract Number DE-AC01-79C.530027

Contract Management by:

Argonne National Laboratory

9700 South Cass Avenue

Argonne, Illino is 60439

G. A. McGinnis, Project Manager 
Synopsis: Solar Energy is a useful tool for accomplishing energy conservation in buildings. The energy collected can be used to displace scarce and expensive fossil fuels. This paper presents guidelines for the professional who may have to choose between competing solar heating and cooling designs for buildings. The author draws on the experience of the National Solar Data Network. in monitoring over 100 solar installations. Three basic principles and a design selection checklist are developed which will aid in choosing the most cost effective design.

Keywords: Solar, heating, cooling, hot water, design 
THIS PAGE

\section{WAS INTENTIONALLY \\ LEFT BLANK}


TABLE OF CONTENTS

Section

Page

Synops is

Table of Contents

List of Tables and Figures

1

3

4

Introduction $\quad 5$

The Three Basic. Principles 6 .

Design Selection Check List 10

A. Overall System 11

B. Collectors 12

C. Storage 13

D. Hot Water 15

E. Space Heating 18

Conclusion $\quad 21$

References $\quad 21$ 
Table

1 Solar Space Heating - Seasonal Performance Office Building in Lynchburg, Virginia

2 Typical Economic Factors for Sites in the National Solar Data Network

3 Thermosiphon System Performance Summary

: 4 . Thermal Performance Calendar Year 1980 Apartment Building, Washington, D.C.

5 Design Selection Checklist

Figure

1 Median Hourly Hot Water Consumption Profile (from NSDN data family sizes $2,3,4$ ) 


\section{INTRODUCTION}

One way to conserve the use of conventional fuels is to use solar energy to replace them in the heating and cooling of buildings or the heating of water. Whether solar energy is economical for a particular application depends on a number of factors. While the solar energy itself is free, the cost of the equipment to collect, store and distribute it can represent a considerable capital investment. The cost of the conventinral fuel which the solar energy will replace has a considerable impact. on cost effectiveness of this investment. We will not concern ourselves here with the decision to use solar, but with the selection of a solar design. This selection might be made after the "go solar" decision or as a preliminary step in the comparison of solar with other conservation options.

The National Solar Data Network (NSDN) has been monitoring the actual operation of solar applications in use throughout the country for over four years. Over 100 installations have been analyzed. These systems are electronically monitored through the day and the data are collected and analyzed by a large computer installation. A description of the system (1) and a 1 ist of free reports available from it (2) can be obtained from the DOE Technical Information Center, P. 0. Box 62, Oak Ridge, TN 37830. The general aralys is and instrumentation scheme is based on a liational Bureau of Standards' document (3).

What we have observed from this network is that there are some excellent systems in the field but also some poor ones. Al though the principles of good basic solar heating and cooling design have been thoroughly studied, they are not well unders tood by the people who designed, selected or built many of the ilistallations. Many of the systems in the NSDN failed or performed ponrly because of poor design practice. True, some good designs were confounded by shoddy or incompetent installation. But an alarining number of designs did not conform to basic solar engineering principles. 
How can a designer avoid these pitfalls? How can a buyer be sure he is accepting a sound design? The experience of the NSDN has shown not only what makes good design, but what are the design errors that are most commonly made and what are the consequence of these mistakes. Adherence to three simple principles together with a list of particular caveats, will help guard against these most common design flaws. The principles and checkpoints gleaned from our analysis work are presented here with illustrations from the NSDN sites.

This is not a design manual. The professional designer has avail-able several excellent textbooks and handbooks which this short paper could not begin to summarize. Neither will these guidelines provide a substitute for thorough engineering analys is of a candidate design. What we mean to provide is direction for a person confronted with alternetives. A designer may want to know which of several different design paths will most likely be fruitful. A buyer presented with several competing designs, may want to know which ones to favor. Or he may want to know if he should accept a single offered design, request more information or seek another.

The guidelines presented here will be directed primarily to active solar heating, hot water, and cooling designs. However, many of the principles can also be applied to passive heating.

\section{TIIL TIIREL DASIC PRINCIPLES}

Three thoughts should quide you in the selection of a solar design. They are very basic. Keep it simple. Keep it cool.. Keep it cheap. The meaning of the first principle is fairly obvious. The second means merely that the design should be able to use solar energy at the lowest temperature that the rest of the system will allow. The third is also obvious. It is not implied that these three basics are the essence of all solar design, but if they are kept in mind throughout the design selection, many common probiems will be avoided. He will look at these ideas now in more detail.

\section{KFEP IT SIMPLE}

A solar heating or cooling installation is already a fairly complex project to begin with. It almost always contains a conventional system as a backup. Over ard above the conventional plant are the solar specific piping or duct work, a controller, storage, pumps, fans, vaives, dampers, etc. All of these additional components increase the system cost, the 
risk of design errors, performance shortfalls and reliability problems. It is important to keep the number and complexity of these components down even if it means selecting a dull, pedestrian solar design.

We agree innovation makes progress. Unfortunately, it also of ten makes failure, especially when it breeds complexity. Your best chance for success for yourself or your client is to stick with the simple, tried, straight-forward, textbook designs.

One common design error that creeps into complex designs is excess parasitic energy. Parasitic energy refers to the energy required to operate the solar components of the system. The terin assumes the solar operation energy is from a conventiona? source such as electricity. As the design complexity increases, the number and size of pumps, fans, motorized valves and dampers and other parasites grow also. He have seen very complex systems use half as much electrical power to deliver solar energy as the solar delivered.

\section{KEEP IT COOL}

"Cool" as used here is a relative term. Solar energy must usually be at least warm to be useful at all. But it is available at varying temperatures throughout the daylight hours, deperding on the angle of the sun and the amount of diffuse radiation. Obviously, the lower the temperature at which you can use it, the more solar energy will be available. Solar collection is also more efficient at lower temperatures.

That sounds simple, but actually this basic principle is harder to realize than the first. The reason is that at the other end of the system, the load end, we are usually looking for relatively high temperatures. Whatever the energy delivery point, whether it be a heat exchanger in an air duct or an absorption chiller, we will get greater efficiency with high temperatures.

Stuck with two conflicting requirements, you should first select a delivery design which will operate effectively at the lowest possibie temperature. Second, accept a lower delivery efficiency in favor of greater solar cncrgy use. In olher words, use solar energy at the lowest temperature the delivery device will accept and still work reasonably efficiently. That is, it will not require such additional operating energy as to offset the benefits of the increased solar participation.

This points up a further paradox in our three principles. Satisfying one may tend to violate the others. For example, one way to lower the solar utilization. temperdture is to use a heat pump to deliver solar energy for heating the building spaces. The heat pump will take solar energy at quite low temperatures and deliver it at high heating temperatures fairly efficiently. This splendidly satisfies the "Keep It Cool" 
principle, but certainly does not keep it simple or cheap. The heat pump is more complex and costly than say, a hot air duct heat exchanger. It will require more complex controls, be harder to design, increase operating cost and may decrease reliability. Will the improved performance justify the additional cost and risk? He will see.

Table 1 is a performance comparison taken from the NSDN of a solar space heating system installed in a small office building and warehouse in Virginia. During the 1978-79 heating season the performance of the solar energy system had been middling. The heating solar fraction had been $33 \%$. Improvement was sought by installing a solar driven heat pump thereby lowering the solar utilization temperature from $105^{\circ} \mathrm{F}$ to $55^{\circ} \mathrm{F}$. As expected, there was a dramatic increase in the solar fraction to $74 \%$ and concurrent decrease in the amount of natural gas auxiliary used for hackup. But the electrical expense required to operate the solar delivery sys lem also increased. The net increase in monelary savings using recent energy costs for the Lynchburg location, was only $\$ 6.00$. . This was certainly not eriough to justify the capital expenditure required by a heat pump.

A solar assisted heat pump might have proven cost effective under different physical and economic conditions. The moral here is that when a design selection puts the basic principles in direct conflict, you had best have a thorough engineering and economic justification for that choice.

\section{KEEP IT CHEAP}

This principle is related to the first in that if you keep the design simple it will probably be inexpensive. Like the others, it may seem obvious, but it is very often violated. When it is, the possibil$i$ ty of any real gain from the sular installation is destroyed. The. application of this principle usually focuses on the collector array as this is generally the most expensive subsystem. In fact, the cost of a solar systell is of ten quoted in dollars per square foot of collector array. However, it is as important to keep the size of the array down as to keep the cost per square foot low: Economies can of course be had in other parts of the systell, aild the total cost of the system shnuld be kept in mind. One way to do this is to determine the conventional energy saved per square foot of collector ared. This can then be related to the cost per square foot of collector area. Table 2 shows some typical ranges of cost and energy savings taken from the NSDN. These ranges are not recommended as targets. In some cases greater or lesser numbers can be obtained. However, they indicate what is achievable at the present state of the art.

Collector cost and energy saved are only rough indicators of economic merit, however. Before a design is selected a lifc cycle cost study 
TABLE 1

SOLAR SPACE HEATING - SEASONAL PERTORMANCE

OFFICE BUILDING IN LYNCHBUURG, VIRGINIA

COMPARISON WITH AND WITHOUT SOLAR ASSISTED HEAT PUMP

\begin{tabular}{|c|c|c|}
\hline & $\begin{array}{l}1978-79 \\
\text { WITHOUT HEAT PUMP }\end{array}$ & $\begin{array}{c}1979-80 \\
\text { WITH HEAT PUHPP }\end{array}$ \\
\hline SOLAR FRACTION & $33 \%$ & $74 \%$ \\
\hline $\begin{array}{l}\text { ENERGY SAVED } \\
\text { (NATURAL. GAS) }\end{array}$ & $24.05 \mathrm{MMBTU}$ & 41.19 MMBTU \\
\hline $\begin{array}{l}\text { ENERGY EXPENSE } \\
\text { (ELECTRICITY) }\end{array}$ & 4.51 MMBTU & 9.83 MMBTU \\
\hline $\begin{array}{l}\text { NET SAVINGS* } \\
\text { (DOLLARS) }\end{array}$ & $\$ 52.00$ & $\$ 58.00$ \\
\hline
\end{tabular}

TABLE 2

TYPICAL ECONOMIC FACTORS FOR SITES IN

IHE 'IATIONAL' SOLAR DATA NETWORK

\begin{tabular}{|c|c|c|c|}
\hline SYSTEM TYPE. & $\begin{array}{c}\text { RANGE OF } \\
\text { COST PER } \\
\text { COLLECTOR AREA } \\
\$ / \mathrm{Ft}^{2}\end{array}$ & $\begin{array}{c}\text { YEARLY RANGE OF } \\
\text { ENERGY SAVED PER } \\
\text { COLLECTOR AREA } \\
\text { BTU/FT }{ }^{2}\end{array}$ & $\begin{array}{c}\text { RANGE OF RETURN } \\
\text { OF INVESTHENT } \\
\text { AFTER INFLATION } \\
. \%\end{array}$ \\
\hline HOT WATER ONIY & 60 to 40 & 290,000 to 190,000 & 18 to 15 \\
\hline $\begin{array}{l}\text { HEATING OR } \\
\text { HOT WATER + HFATING }\end{array}$ & 50 to 30 & 180,000 to 70,000 & 20 to 2 \\
\hline
\end{tabular}


must.be done. Several life cycle cost indicators are in use such as pay back period. We prefer the annual return on investment (ROI) after inflation. This figure is easy to understand and you can determine what is an acceptable return based on your particular circumstances. A range of figures from the NSDiv is also given in Table 2.

A common mistake in this area which often leads to failure is to go for a very large solar fraction. Large solar fractions usually entail large collector arrays. They may also require expensive collectors, controllers, or other high cost equipment. It is better to accept a smaller solar fraction in order to achieve an economical design. The important thing to concentrate on is significant energy savings. The solar fraction is only a design measure useful in achieving that end. In commercial or industrial application with. large loads a small solar fraction of say $10 \%$ to $15 \%$ might result in significant energy savings. of course, the cost of the conventional fuel being replaced can also have considerable impact.

It is notable that Table 2 has no figures for cooling applications. The NSDN has monitored several representative active solar cooling systems. None has shown significant energy savings. Most are net energy losers. The only commercially feasible active solar cooling strategy at this time involves using absorption type air conditioners. These machines were originally developed to use fossil energy to heat a refrigerant mixture such as water-lithium bromide and solar energy can be used as the heat source. Unfortunately, it is very difficult lo adhere to the three principles with this type of design. The absorption air conditioners of ten require temperatures above $180^{\circ} \mathrm{F}$ to operate efficiently thus making it difficult to "keep it cool." The absorption chiller is usually augmented by a separate conventional compressed vapor cycle electric a ir conditioner. Modern vapor cycles operate at COP's up to 4.5 whereas the solar driven absorption machine typically operates at a COP of 0.6 to 0.7 . High performance collectors, sophisticated control systems, additional storage and other strategies are required to overcome the high temperature requirements and low COP. All of this of course drives up the compiexity and cost. This is not to say that a successful active solar cooling design is not possible, but a successful design has not been demonstrated in the NSDN.

\section{DESIGN SELECTION CHECK LIST}

While we feel the most important considerations for successful solar design selection are the three basic principles, our experience in the NSDN has revealed many other important. points which should be kept in mind. We have assembled them below in a check 1 ist format for use in evaluating a particular design candidate. In some cases, technical data from the NSDil is given to illustrate a point. More detail on these quidelines can be fourd in reference (4). 
The check list is arranged in sections and each point is given a short title as a memory aid.

\section{A. Overall System}

1. Concentrate on Controls. The control system and control strategy are perhaps the most difficult part of the solar system design. It is more important here than anywhere else to demand competent, thoughtful design. This is the most important area to determine how you can keep the whole system simple, cool and cheap. It is not possible to give any simple rules of thumb. for control system design. This is the brains of the system and it demands the most "brains" in design.

2. Control Losses. Just because the solar energy is free does not mean it should not be preserved. You must deliver enough solar to the load to justify your capital investment. Insulation is a must on all solar piping and ducting. Uncontrolled losses into the heating space, while contributing useful energy, can cause uneven distribution of space heating and increase the cooling load. Systems using air collectors are particularly susceptible to uncontrolled losses caused by leakage from ducts. Beside the detrimental effects described above, this leakage can increase the building infiltration. This can be minimized by putting the collector loop fan in the collector to storage leg (5). Sealed ducts are preferred. Outdoor storage should be very well insulated and the insulation protected from inoisture, especially ground water.

3. Control Corrosion. Many liquid based solar designs leave portions of liquid loops open to the atmosphere. This makes them more susceptible to corrosion than conventiona? HVAC designs. Some designs use antifreeze for protection of the collector components. This may make periodic and expensive replacement of the fluid necessary as corrosion inhibitors deteriorate. Dissimilar metals such as copper and steel in the same. loop should be avoided unless galvanic protection is provided. Air sys.tems are much less susceptible to corrosion problems.

4. Provide Monitoring. It is important to know that the systen is operating properly. Most NSDN installations have experienced problems, especially during start up, which could not have been discovered wi thout some ins trumentation being available. Investing a few hundred dollars in sonie basic instrumentation and indicators can save thousands. 
5. Minimize Maintenance. Because of the additional equipment, the solar energy systell will be more complex than a conventional HVAC sys tem. Yet users are not likely to spend appreciably more effort in maintaining and operating the system than for a conventional system. Therefore, it is important to keep operational and nia intenance requirements to a minimum. This is especially true in a residential environinent where the technical expertise to provide for maintenance may not be availabie.

6. Analyze the Economics. It is often difficult to keep the economic considerations in mind while immersed in the technical considerations of a design selection. Yet the bottom line is always the dollar savings and whether or not it justifies the cost of the system. Always demand a thorough economic analys is based on real istic projectlons of fuel cost and other economic factors and a conservative estimate of system performance.

\section{B. Collectors}

1. Minimize the Array. Collectors are usually the biggest subsystem expense for the system. Be sure the size of the array is the smallest that will do the job satisfactorily and the type and model seiected are the most economical. This may seem obvious but it is of ten forgotten. Expensive tracking collectors have been used where cheaper flat plate designs would have sufficed.

2. Avoid Shading. Most people are aware of the dangers of collector shading by trees or adjacent buildings but collector self-shading is frequently found. That is, where collectors are arranged in rows the forward rows can block part of the suri from the after rows.. A typical error is to check for self-shading for the noonday sun at winter solstice. This may still allow considerable shading during the morning and afternoon hours of the short winter day.

3. Expect Less. Experience in the NSON indicates that collector array performance in the field is usually lower than the laboratory measured efficiency curves given by manufacturers (6). The laboratory curves are taken on single panels under test conditions specified by ASIIRAE (7). The reasoris for the dtfferenes are not clear but may be due to nonuniform flow patterns in the array or deterioration. of the collector. components. The only guidel ine which can be given here is to design corservatively and pay particular attention to flow rates in a!l parts of the array. 


\section{Storage}

1. Favor Stratification. Temperature stratification in storage tanks is almost always beneficial. It presents one way to resolve the conflict between the low temperatures favored by the solar end and the high temperatures required at the load end. Simply feed the collector array from the cool bottom of the stratified tank (or box) and accomnodate the load from the hot top. Probably because it simplifies design calculations, some designers have gone so far as to install pumps to keep the storage tank fully mixed. This should be avoided. In fact, it is often advisable to install baffles or other devices in storage tanks to encourage stratification.

Table 3 illustrates the advantage of stratification. This shows a comparison of actual versus theoretical performance results for a thermosiphon solar hot water system on an apartment house in Honolulu, HI. A reference system simulation using the laboratory collector specifications but assuming a fully mixed tank was performed. Since the flow in the thermosiphon array was much less than the laboratory test conditions, the array performance should have been degraded. However, the benefits of the fully stratified storage tank counteracted this and the actual performance is virtually identical to the simulated active system.

2. Bypass Storage. Some portion of any energy put in storage will be lost. No one has yet invented the perfect insulation. Therefore, when there is a dernand at the load end of the system and there is useful solar energy available from the collectors it should be provided directly. That is, there should be some means for bypassing solar energy around (or through, for air) storage and directly to the delivery device.

3. Exclude Auxiliary. The conventional auxiliary energy is What we are trying to conserve. It is almost always available on demand. There is seldom any reason to put auxiliary energy in the solar storage device where sume of it will be needlessily lost. Avoid designs which allow auxiliary energy to go to storage unless they are strongly justified by other considerations (load management, for instance).

4. Size Carefully. There may be a temptation to use a storage devlce which is available, in a retrofit for instance. Don!t give in. If the storage device is of the wrong size, it can seriously affect performance. So using an available. 
storage device may be false economy. Any solar design textbook will describe how to select the proper storage size.

TABLE 3

THERMOSIPHON SYSTEM PERFORMANCE SUMMARY APRIL 1980 - MARCH 1981

\begin{tabular}{lcc} 
& $\begin{array}{c}\text { ACTUAL } \\
\text { SOLAR } \\
\text { FRACTION } \\
\%\end{array}$ & $\begin{array}{c}\text { REFFRFNCF* } \\
\text { SOLAR } \\
\text { FRACTION } \\
\%\end{array}$ \\
\hline APR & 99 & 90 \\
MAY & 95 & 100 \\
JUN & 98 & 94 \\
JUL & 98 & 98 \\
AUG & 98 & 100 \\
SEP & 98 & 100 \\
OCT & 95 & 100 \\
NOV & 97 & 100 \\
DEC & 98 & 100 \\
JAN & 96 & 100 \\
FEB & 96 & 100 \\
MAR & 99 & 96 \\
YR AVG & 97 & 98
\end{tabular}

* Simulation of a reference active system using FCHART 4.0. See text. 


\section{Hot Water}

1. Accommodate Losses. Designing for the peak hot water demand is standard practice for service hot water. While this is important for fast recovery from hot water draws, it is important in designing the solar hot water system to consider losses from the hot water heater tank and associated. piping. This is especially true if there is a recirculation loop. In retrofit hot water applications in large residential complexes, the losses from uninsulated recirculation loops often exceed the energy delivered to users. It is important to design the system so that solar energy can make up a portion of the recirculation losses in such cases. As a conservation measure, you might consider whether a recirculation loop is really necessary.

The effect of the recirculation losses and the solar system design to accommodate them is seen in data in Table 4 taken from a large apartment building in Washington, D. C. The hot water energy losses can be seen as the difference between the demand column and the demand pius losses column. Notice, the recirculation losses are greater than $100 \%$ of the demand for most months prior to June 1980 . In June, several changes were made to decrease the recirculation loop losses and to allow solar to participate in the recirculation loop load. During the months of July, August and September, the recirculation pump was disabled due to inechanical problems. Note the dramatic decrease in losses. After the loop was restarted in 0ctober, the recirculation losses are again evident but are reduced somewhat. The solar fraction in the last. three months is substantially higher than the first three months of the year even though the insolation is lower. The energy savings are also improved. This is largely because of the ability of solar energy to participate in the recirculation load after the changes:

2. Design for Morning. Designs for residential hot water applications sliould expect the peak load in the morning.

This is based on a study of NSON sites which analyzed data from 15 single family dwellings and 202 apartments ( 8 ). The load profile from this study is shown in Figure 1 .

3. Should You Combine? Consider carefully any combination of a hot water application with another application such as space heating. Such designs have been successful. However, many have not. The system must be sized for the heating load. Will the operating energy required to use the system over the sunmer months detract from the hot water energy savings? Also, will losses from the system during this 
season add to the cooling load? Consider whether the system should be secured during the cooling season.

\section{TABLE 4}

THERMAL PERFORMANCE CALENDAR YEAR 1980

APARTMENT BUILDING, WASHINGTON, D. C.

\begin{tabular}{ccccccc} 
MONTH & $\begin{array}{c}\text { INSOLATION } \\
\text { MMBTU }\end{array}$ & $\begin{array}{c}\text { SOLAR } \\
\text { FRACTION } \\
\%\end{array}$ & $\begin{array}{c}\text { HOT WATER } \\
\text { DEMAND } \\
\text { MMBTU }\end{array}$ & $\begin{array}{c}\text { HOT WATER } \\
\text { DEMAND \& LOSSES } \\
\text { MMB IU }\end{array}$ & $\begin{array}{c}\text { ENERGY SAVINGS } \\
\text { FOSSIL } \\
\text { MMBTU }\end{array}$ & $\begin{array}{c}\text { ELETRICAI } \\
\text { MMBTU }\end{array}$ \\
\hline JAN & 61.9 & 12 & 44.9 & 119.3 & 24.5 & -0.9 \\
FEB & 102.5 & 25 & 38.3 & 106.1 & 42.8 & -1.5 \\
MAR & 104.1 & 26 & 62.0 & 111.8 & 48.1 & -1.8 \\
APR & 111.5 & 22 & 20.9 & 92.4 & 33.3 & -1.1 \\
MAY & 122.4 & 25 & 18.5 & 80.1 & 33.7 & -1.2 \\
JUN & RECIRCULATION LOOP & CONFIGURATION CHANGED & & \\
JUL & 143.3 & 69 & 59.5 & 65.7 & 75.0 & -2.7 \\
AUG & 153.3 & 70 & 60.3 & 61.4 & 71.2 & -2.8 \\
SEP & 117.7 & 62 & 55.4 & 61.2 & 63.1 & -2.2 \\
OC.T & 36.9 & 38 & 50.4 & 89.4 & 56.8 & -1.6 \\
NOV & 89.1 & 29 & $67 . ?$ & 103.5 & 50.1 & -1.1 \\
DEC & 73.5 & 17 & 74.2 & 112.5 & 31.7 & -1.1
\end{tabular}




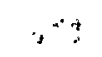

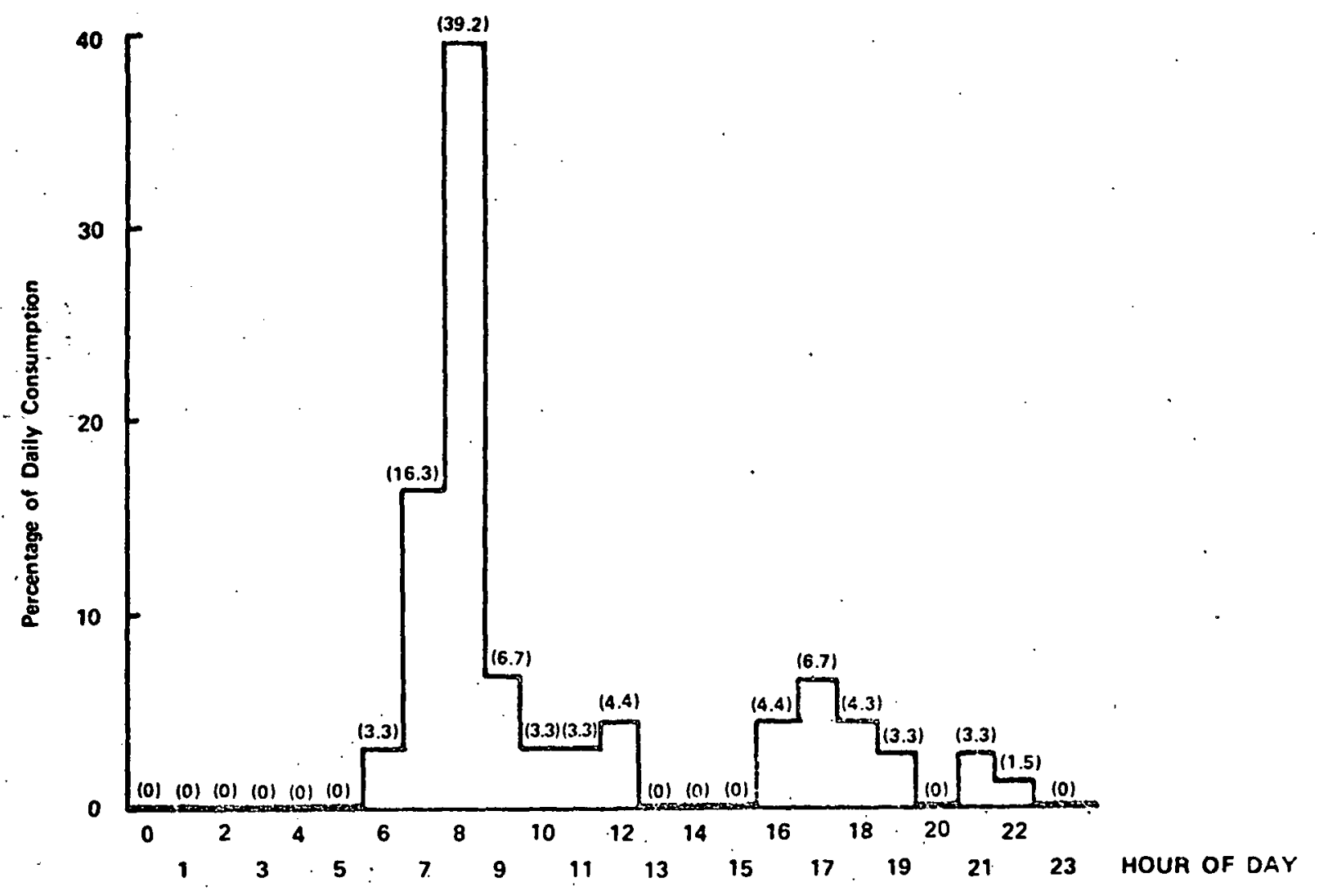

Figure 1. Median Hourly Hot Water Consumption Profile (from NSDN data family sizes $2,3,4$ ) 


\section{E. Space Heating}

1. Err on the Low Side. Calculating the load accurately is very difficult. For conventional heating systems, it is generally necessary to err on the high side so that peak hea ting needs are met. However, this is not true for solar applications. Because you must keep it cheap to select a successful design, it is more important not to oversize the solar components, particularly the collector array. So it is best to consider that the calculated load may be too high when sizing the solar system and too low when sizing the conventional system.

2. Off in Sumner. If the system has a heating application only, be sure it can be secured during the cooling season. This will save operating energy and avoid adding to the cooling load. However, provision should be máde to protect the collectors from possible stagnation damage.

\section{F. Space Cooling}

As stated earlier, we have no successful solar space cooling systems in the NSDN. We therefore have no concrete guidelines to provide. We can only recommend that the three basic principles be applied. We consider the bullding of an active solar cooling system a risky venture at this time.

\section{G. Passive Systems}

While we have not featured jassive systems here, many of the check points listed above can be applied. In addition, we would add the following:

1. Insulate at Night. Passive space heating systems have large areas of glazing on the south side to provide solar gain. If these are not provided with insulation during periods of low solar radiation, they can impose enormous losses. Some methods of computing solar fractions for passive systems do not account for the fart. that these losses would not occur in a conventional building.

2. Operate Automatically. Having said that night insulation is necessary, we now add that it is important that the occupants not be required to put it in place and remove it manually. The performance of a system is an inverse function of the aimount of owner intervention required to operate $i t$. The building should be designed considering that the present occupant may be replaced by someone who is rot capable or willing to operate the system manually. 
TABLE 5

DESIGN SELECTION CHECKLIST

A. OVERALL SYSTEM

$\square$ 1. Concentrate on Controls. The "brains" takes lots of thought.

2. Control Losses. Make sure the solar energy goes where you want it.

3. Control Corrosion. Open systems and antifreeze can cause probiemis.

$\square$ 4. Provide Monitoring. What you don't know can cost you.

[] 5. Minimize Maintenance. If they won't change a filter, they won't drain a collector.

$\square$ 6. Analyze Economics. The return on your investment is the thing.

B. COLLECTORS

$\square$ 1. Minimize the Array. No bigger or fancier than you need.

2. Avoid Shading: Full exposure at high noon is not eriough.

3. Expect Less. Panel collection in the lab is not like array's in the field.

C. STORAGE.

1. Favor Stratification. Storage stratification is good for the solar.

2. Bypass Storage. Direct from the collector when needed.

3. Exclude Auxiliary. Never store conventional energy.

4. Size Carefuliy. Don't use storage built for another system.

D. HOT WATER

2. Accommodate Losses. Let solar help rep?ace DHW losses:

2. Design for Morning. Peak load is in the a.m. in homes.

3. Should You Combine? Should DHW and SH go together?

E. SPACE HEATING

$\square$ 1. Err on the Low Size. Never oversize the solar components.

$\square$ 2. Off in Summer. If hea ting only, winter only.

F. SPACE COOLING - Risky

G. PASSIVE SYSTEMS

$\square$ 1. Insulate at Night. Night insulation of glazing a must.

2. Operate Automatically. As little owner intervention as possible.

NOW, IS IT SIMPLE - IS IT COOL - IS IT CHEAP? 
CONCL.USION

Many textbooks and manuals are available to enable the design professional to achieve a satisfactory design after rigorous computation. No simple guidelines, based on field experience, have been available to assist in the choice between alternate designs. The designer, his client and other interested parties to the design selection process need such assistance. This paper presents a basic approach using three basic principles auginented by specific guidelines. This is summarized in Table 5 in the form of a single sheet check list. The explanations on the check list" are terse and are mearit only ds reminders of the inore complete explanations contained in the text.

Remember. Keep it simple! Keep it cool! Keep it cheap!

\section{REFERENCES}

(1) The National Solar Data Network, SOLAR/0003-80/17, DOE, January 1980.

(2) Availability of Solar Energy Reports from the National Solar Data Program, SOLAR/0020-81/44, JuTy 1981.

(3) Thermal Data Requirements and Performarice Evaluation Procedure for the National Solar Heating and Cooling Demons tration Program, NBSIR 76-1137, National Bureau of Standards, August 1976.

(4) Holte, H: and C. J. Kelly, Solar Design ard Installation Experience: An Overview of Results from the National Solar Data Netilork, SOLAR/0009-81/37, DOE, September 1981.

(5) Jones, D. et al, "Air Leakage Effects on Active Air-Heating Solar Collector System Performance," Proceedings of the 1980 Annual Meeting AS of ISES, 1980.

(6) McCumber, W., Collector Array Performance Report for Sites of the National Solar Heating and Cooling Demonstration Program, Volumes 1 and 2, SOLAR/O021-79/38, DOE, JuTy 1979 .

(7) Methods of Testing to Determine the Thermal Performance of Solar Collectors, ASHRAE Standard 93-77, (1978).

(8) Barvir, E. et al, "Hourly Use Profile for Solar Donestic Hot Water Heaters in the National Solar Data Network," Proceedings of the ASME Solar Energy Division, Third Armual System Simulation and Economic Analysis, Solar Heating and Cooling Operational Results Conference, Aprit 1981. 